\title{
都市在住者における犯罪および犯罪報道についての意識 一葛飾区・杉並区調査のデータから一
}

Attitude to crime and crime reporting in urban residents -Analysis of survey data of Katsushika and Suginami residents-

\author{
牧野 智和 1 \\ 1 大妻女子大学人間関係学部
}

Tomokazu Makino

${ }^{1}$ Faculty of Human Relations, Otsuma Women's University

2-7-1 Karakida, Tama-City, Tokyo, 206-8540 Japan

キーワード : 治安, 犯罪, 犯罪報道, 態度, マスメディア

Key words : Security, Crime, Crime reporting, Attitude, Mass media

\section{— 抄録}

治安や犯罪に対する人々の態度の調査分析は, 未だその知見が蓄積途上にある. そこで本稿では， 2019 年度における大妻女子大学人間関係学部社会学専攻の 2 年次科目「社会調査及び演習」におい て行われた「東京のライフスタイルと社会意識に関する調查」に設けられた犯罪および犯罪報道に 関する調査項目の分析結果を報告する。単純集計レベルにおいて興味深い点は，治安・犯罪情報の 入手においてかつて圧倒的であったテレビ・ラジオと新聞の牙城が崩れ，インターネットが急激に 台頭していることである．クロス集計および重回帰分析において興味深い点は，子どもの有無がマ スメディアの犯罪報道に対する評価に一貫した効果を及ぼし，情報入手に利用するメディアにした がってマスメディア報道の正当化あるいは相対化する傾向がみられるということであった.

\section{1. 本資料の意義}

犯罪に関する社会調査およびその分析は，内閣 府「治安に関寸る世論調査」, 警察庁「全国統一治 安意識調査」, 日工組社会安全研究財団「犯罪に対 する不安感等に関する調查研究」など，(体感）治 安や犯罪不安を中心になされてきた。こうした調 査のなかで，治安や犯罪に対する人々の態度もま た調査・分析されてきたが，未だ焦点を当てられ ていないことがらは多く，知見は未だ蓄積途上に あると思われる。そこで本稿では，2019年度にお ける大妻女子大学人間関係学部社会学専攻 2 年次 科目「社会調査及び演習」において行われた「東 京のライフスタイルと社会意識に関する調査」に 設けられた犯罪および犯罪報道に関する調查項目 の分析結果を報告し, 知見蓄積の一助としたい.

\section{2. 調査概要}

上記科目を受講した学生 (演習は 2 クラス開講)
が提案した調査項目を，それぞれの担当教員（久 保田滋，牧野智和）および大学院生 TA の指導・ サポートのもとワーディングを整え，調査は行わ れた. 調査対象者は東京都葛飾区・杉並区に住む， 18 歳から 69 歳の男女である. 標本抽出台帳とし て同区の選挙人名簿を用い，系統抽出法により 1600 名の標本を抽出した. 2019 年 9 月に調査票を 発送し，督促状を 1 回発送した。発送数 1600 票に 対して有効回収数は 450 票であり, 有効回収率は 28.1\%であった．調査票においては，基本属性のほ か，生活や家族・仕事などについての満足度，メ ディア利用，政治・家族・教育・労働・犯罪等に ついての意識を質問している.

\section{3. 単純集計結果}

犯罪および犯罪報道に関する調査項目の単純集 計結果をまず報告する（調査票全体の単純集計結 果は人間関係学部のホームページに掲載されてい 
る). 図 1 は逸脱行動・犯罪の増減についての認識 を聞いた項目の調查結果だが，これは既存の調査 でもしばしば聞かれる内容のものである。それら の調査結果と同様に, 各種の逸脱行動・犯罪は「ど ちらかといえば増えている」を含め, 大多数が「増 えている」と認識されていることがわかる.

次に，非行・犯罪とその被害についての意識を 聞いた項目の調査結果が図 2 である。量的な増減 に加え,「未成年による非行・犯罪は悪質になって いる」の肯定回答率は $86.1 \%$ にのぼり, 質的な 悪化もまた認識されていることがわかる．また，

「未成年による非行・犯罪は今よりもっと厳しく
処罰されるべきだ」への肯定回答率は実に 90.3\% にのぼり, 㛜罰化要求も非常に強いといえる。性 犯罪被害については, 「性犯罪の被害者が被害に遭 ったことを届け出るのは非常に大変なことだ」と いう強い表現の選択肢を設けたが，肯定回答率は 99.1\%にのぼり,このことについての困難性は広く 共有されているといえそうである。だが「服装な ど見た目の印象によって性犯罪被害に遭いやすい かどうかが変わってくる」の肯定回答率は $75.1 \%$ と高く, 被害者の自己責任論にも通じるような意 識もまた根強いことがわかる。

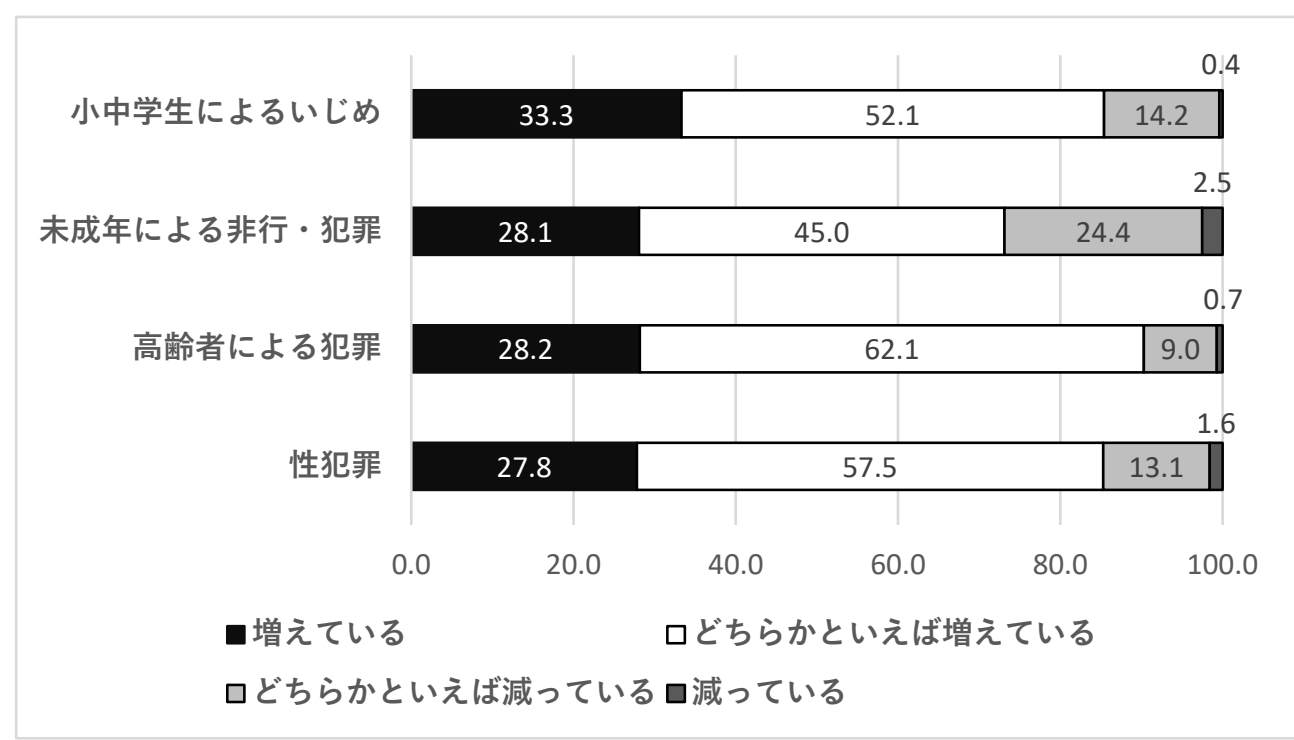

図 1 逸脱行動・犯罪の増減についての認識

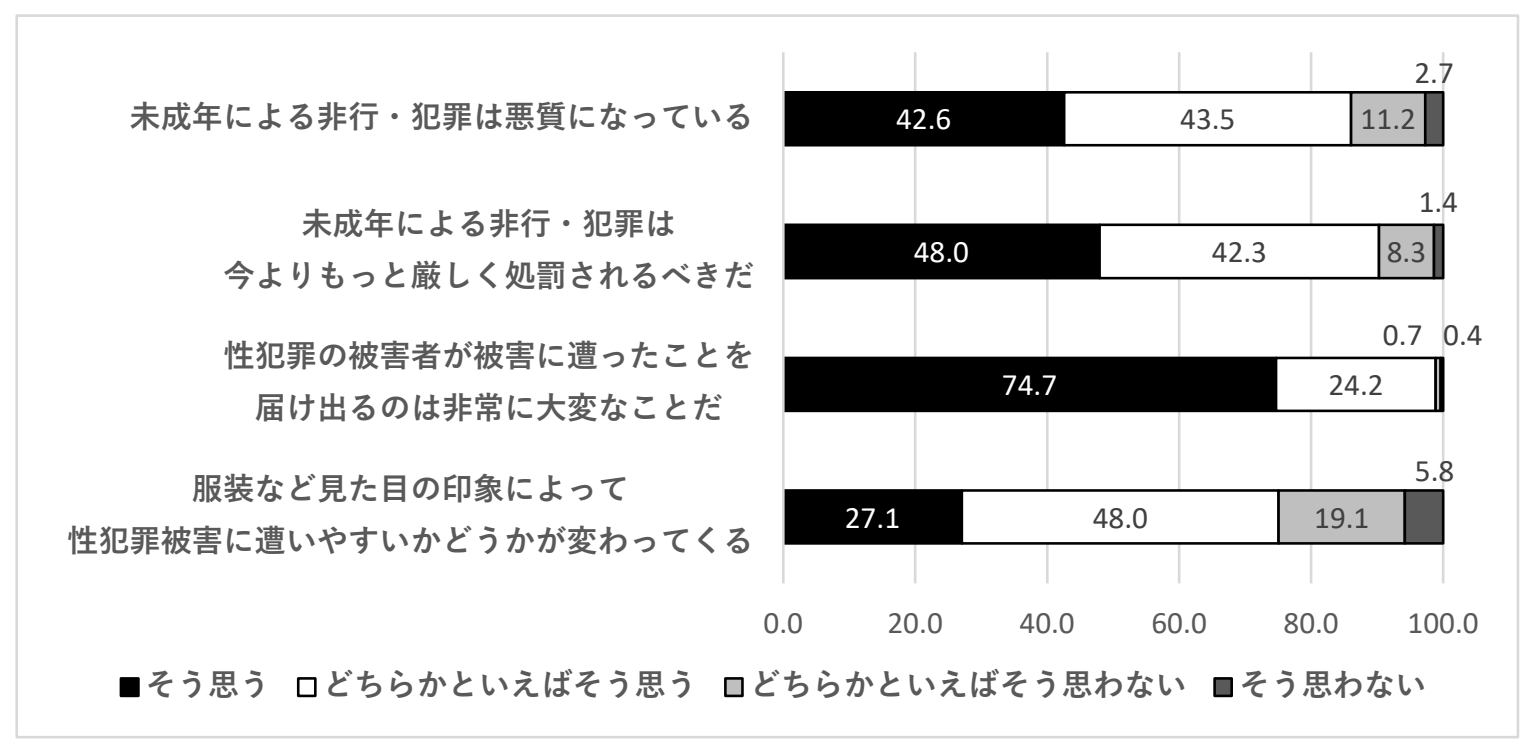

図 2 非行・犯罪とその被害についての意識 


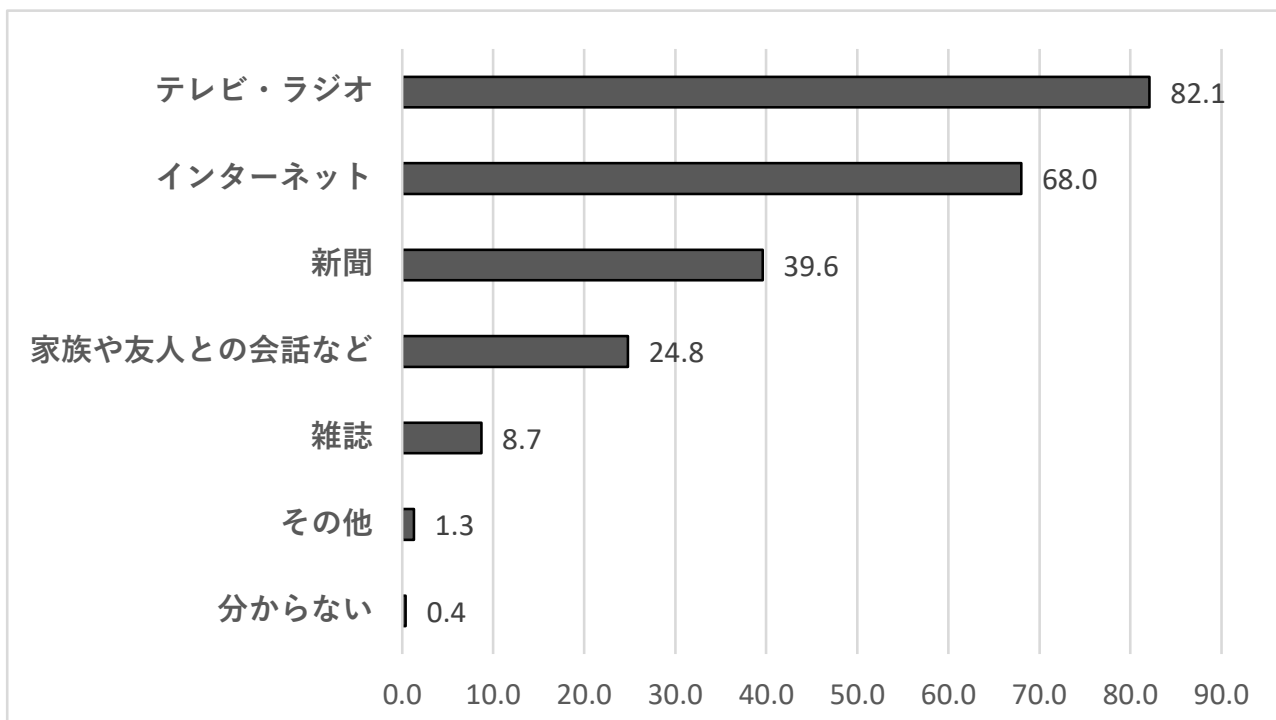

図 3 治安や犯罪に関する情報の入手源

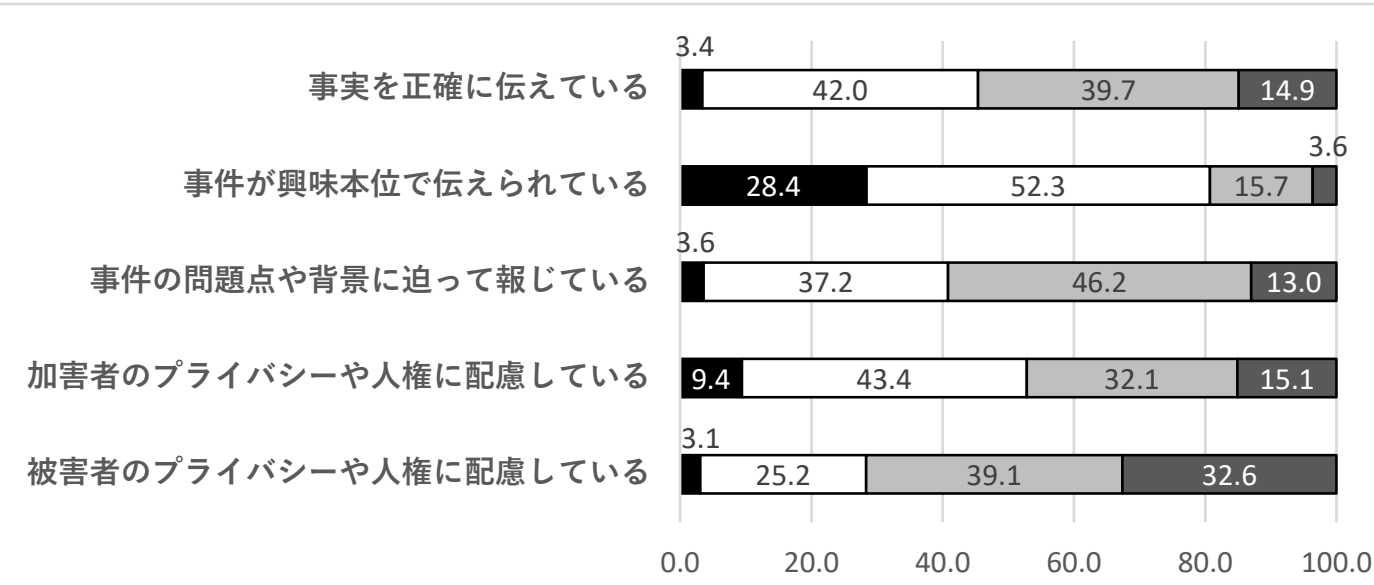

ロそう思う ロどちらかといえばそう思う ロどちらかといえばそう思わない ロそう思わない

図 4 マスメディアでの犯罪報道についての意識

困 3 は，治安や犯罪に関する情報の入手源を聞 いた項目の調查結果である。この調査項目は，内 閣府「治安に関する世論調査」の 2004 年と 2006 年の調査において用いられていたものだが，2012 年と 2017 年の同調査では項目が割愛され, 同内容 の調査が管見の限りではなかったように思われた ため, 同調査の項目をほぼそのまま用いたもので ある。2006 年の調査結果では，テレビ・ラジオが $95.5 \%$ と圧倒的に高く, ついで新聞 $(81.1 \%)$, 家族 や友人との会話など $(38.4 \%)$ と続き，インターネ ットは $21.6 \%$ に留まっていた. だが図 3 をみて分 かるように，圧倒的だったテレビ・ラジオの牙城 は崩れ，新聞は半分以下に落ち込んでいる。代わ
つて急激に台頭しているのがインターネットであ る。もちろん，これは東京在住者の一調査結果に 過ぎないが，図 1 や図 2 で示した調査結果が既存 の官公庁統計と重なる部分が多くあることを考え ると, 図 3 の結果は 2006 年から 2019 年の間のメ ディア環境の変化のある部分を映し出していると いってよいように思われる。

困 4 は，マスメディアでの犯罪報道についての 意識を聞いた調査結果である。図 3 で示したよう に，犯罪報道におけるマスメディアの位置はかつ てのような圧倒的なものではなくなっているが， その報道のあり方についての人々の意識もなかな か手㛜しいものがあるといえる。「事実を正確に伝 
えている」の肯定回答率は $45.4 \%$,「事件の問題点 や背景に迫って報じている」は $40.8 \%$ と半分に届 かず，それに対して「事件が興味本位で伝えられ ている」は 80.3\%である。「加害者のプライバシー や人権に配慮している」は 52.8\%でこれ自体高い とはいえないが,「被害者のプライバシーや人権に 配慮している」は28.3\%とかなり低い状況にある。
もちろん, マスメディアの犯罪報道という表現は 曖昧にすぎ，玉石混交の報道のうち「石」の方を 思い出して回答した結果が図 4 だという可能性は 大いにあるのだが，総体的な態度として，マスメ ディアに対する不信がかなりの程度広がっている 状況なのではないかと考えられる.

表 1 主だった属性項目とのクロス集計（\%)

\begin{tabular}{|c|c|c|c|c|c|c|c|c|c|}
\hline & \multicolumn{2}{|c|}{ 性別 } & \multicolumn{3}{|c|}{ 年代 } & \multicolumn{2}{|c|}{ 居住自治体 } & \multicolumn{2}{|c|}{ 本人学歴 } \\
\hline & 男 & 㚣 & $\begin{array}{l}3 \\
9 \\
5\end{array}$ & $\begin{array}{l}4 \\
0 \\
5 \\
5 \\
9\end{array}$ & $\begin{array}{l}6 \\
0 \\
S\end{array}$ & $\begin{array}{l}\text { 葛 } \\
\text { 飾 } \\
\text { 区 }\end{array}$ & $\begin{array}{l}\text { 杉 } \\
\text { 並 } \\
\text { 区 }\end{array}$ & $\begin{array}{l}\text { 大 } \\
\text { 卒 }\end{array}$ & $\begin{array}{l}\text { 非 } \\
\text { 大 } \\
\text { 卒 }\end{array}$ \\
\hline 小・中学生によるいじめが増えている & 83.5 & 86.9 & 84.4 & 82.5 & 90.4 & 86.2 & 84.4 & $\underline{81.9}$ & $\underline{89.3}$ \\
\hline 未成年による非行・犯罪が増えている & 72.1 & 74.0 & $\underline{\underline{63.3}}$ & $\underline{\underline{72.0}}$ & $\underline{\underline{86.6}}$ & $\underline{77.9}$ & $\underline{68.2}$ & 69.6 & 77.3 \\
\hline 高齢者による犯罪が増えている & 88.7 & 91.5 & 89.8 & 91.2 & 89.4 & 92.3 & 88.1 & 88.6 & 92.2 \\
\hline 性犯罪が増えている & $\underline{\underline{78.8}}$ & $\underline{\underline{91.1}}$ & $\underline{78.7}$ & $\underline{88.1}$ & $\underline{88.4}$ & 86.4 & 84.4 & $\underline{\underline{79.3}}$ & $\underline{\underline{92.6}}$ \\
\hline 未成年による非行・犯罪は悪質になっている & 83.1 & 89.0 & $\underline{\underline{76.6}}$ & $\underline{\underline{87.1}}$ & $\underline{\underline{94.8}}$ & 88.9 & 83.5 & $\underline{\underline{80.2}}$ & $\underline{\underline{93.2}}$ \\
\hline $\begin{array}{l}\text { 未成年による非行・犯罪は } \\
\text { 今よりもっと玈しく処罰される心゙きだ }\end{array}$ & 92.2 & 88.6 & 85.9 & 92.3 & 92.1 & $\underline{93.8}$ & $\underline{86.7}$ & $\underline{\underline{86.5}}$ & $\underline{\underline{94.7}}$ \\
\hline $\begin{array}{l}\text { 性犯罪の被害者が被害に遭ったことを } \\
\text { 届け出るのは非常に大変なことだ }\end{array}$ & 99.0 & 98.8 & 97,7 & 100.0 & 98.3 & 98.2 & 99.5 & 98.7 & 99.0 \\
\hline $\begin{array}{l}\text { 服装など見た目の印象によって性犯罪被害に遭い } \\
\text { やすいかどうかが変わってくる }\end{array}$ & 77.8 & 73.3 & $\underline{\underline{71.1}}$ & $\underline{\underline{70.6}}$ & $\underline{\underline{87.8}}$ & 79.1 & 71.6 & 76.4 & 74.4 \\
\hline 治安情報入手先 : テレビ・ラジオ & 80.3 & 83.9 & $\underline{\underline{71.7}}$ & $\underline{\underline{83.0}}$ & $\underline{\underline{91.5}}$ & 81.4 & 83.0 & 79.3 & 85.6 \\
\hline 治安情報入手先 : インターネット & 70.2 & 66.1 & $\underline{\underline{89.0}}$ & $\underline{\underline{73.7}}$ & $\underline{\underline{38.5}}$ & $\underline{\underline{59.7}}$ & $\underline{\underline{76.6}}$ & $\underline{\underline{78.1}}$ & $\underline{\underline{56.7}}$ \\
\hline 治安情報入手先 : 新聞 & 41.8 & 37.7 & $\underline{\underline{17.3}}$ & $\underline{\underline{41.8}}$ & $\underline{\underline{60.7}}$ & 38.9 & 40.4 & 43.5 & 35.1 \\
\hline 治安情報入手先 : 家族や友人との会話など & 21.6 & 28.0 & 26.8 & 28.4 & 18.8 & 26.5 & 23.4 & 22.8 & 27.4 \\
\hline $\begin{array}{l}\text { (マスメディアの犯罪報道は) 事実を正確に伝えて } \\
\text { いる }\end{array}$ & 44.9 & 45.5 & $\underline{\underline{33.9}}$ & $\underline{\underline{45.8}}$ & $\underline{\underline{56.5}}$ & $\underline{50.0}$ & $\underline{40.3}$ & $\underline{\underline{38.7}}$ & $\underline{\underline{52.4}}$ \\
\hline （同）事件が興味本位で伝えられている & 80.3 & 80.9 & 82.8 & 82.4 & 75.2 & $\underline{\underline{75.8}}$ & $\underline{\underline{85.8}}$ & $\underline{\underline{86.9}}$ & $\underline{\underline{73.7}}$ \\
\hline （同）事件の問題点や背景に迫って報じている & $\underline{\underline{31.3}}$ & $\underline{\underline{49.4}}$ & 44.5 & 43.5 & 31.9 & $\underline{46.0}$ & $\underline{35.5}$ & 37.9 & 44.0 \\
\hline (同) 加害者のプライバシーや人権に配慮している & 57.2 & 49.4 & 44.5 & 55.4 & 58.6 & 51.3 & 54.8 & 48.3 & $\underline{58.4}$ \\
\hline (同) 被害者のプライバシーや人権に配慮している & 29.3 & 27.2 & 21.9 & 28.5 & 34.5 & $\underline{\underline{34.1}}$ & $\underline{\underline{22.1}}$ & $\underline{\underline{22.2}}$ & $\underline{\underline{34.9}}$ \\
\hline
\end{tabular}

※一重下線はカイ二乗検定の結果 5\%水準で，二重下線は同じく $1 \%$ 水準で統計的に有意な差がみられたことを示す.

\section{4. クロス集計}

次に，性別，年代（39 歳まで，40・50 代， 60 歳以上で三分割したもの)，居住自治体，本人学歴 （大卒・非大卒）という属性項目を用いて各項目 のクロス集計を行ったものが表 1 である.
統計的に有意な差が出た組み合わせが多岐にわ たるので網羅的な言及は行わないが，いくつか興 味深いと思われた点を指摘しておきたい。まず，

「未成年による非行・犯罪が増えている」「未成年 による非行・犯罪は熏質になっている」はそれぞ 
れ若年層において最も肯定回答率が低く, 高年層 が最も高い結果になっている. また年代について は，治安・犯罪に関する情報入手源が劇的といっ てもよいほどに異なり, 若年層はインターネット に, 高年層はテレビ・ラジオや新聞といったマス メディアに強く寄っている.またこれに伴ってか, 「(マスメディアの犯罪報道は) 事実を正確に伝え ている」も年代ごとの傾斜がみられる.

居住自治体でいくつか差がみられることも興味 深い.「未成年による非行・犯罪が増えている」「未
成年による非行・犯罪は今よりもっと喛しく処罰 されるべきだ」がともに，葛飾区居住者の方が高 い結果になっている。 また，マスメディアに対す る不信は杉並区居住者の方がおおむね高い。学歴 に関しては，概して大卒者の方が穏当で，またマ スメディアに対する不信が強い結果になっている のだが，居住地域による回答傾向の違いはこうし た回答者の社会経済的地位に由来するものなのか, それとも居住地域それ自体に由来寸るものなのだ ろうか.

表 2 未成年による非行・犯罪の認識についての重回帰分析

\begin{tabular}{lrrrr}
\hline & $\mathrm{B}$ & \multicolumn{1}{c}{ S.E. } & \multicolumn{1}{c}{$\beta$} \\
\hline (定数) & 3.322 & $* *$ & 0.461 & \\
女性ダミー & 0.047 & & 0.076 & 0.030 \\
年齢 & 0.009 & $* *$ & 0.003 & 0.165 \\
杉並区居住ダミー & -0.088 & 0.080 & -0.057 \\
子どもありダミー & 0.005 & 0.086 & 0.003 \\
本人教育年数 & -0.061 & $* *$ & 0.023 & -0.144 \\
世帯年収 & 0.024 & 0.022 & 0.057 \\
情報入手源 : 新聞 & 0.078 & 0.082 & 0.049 \\
情報入手源 : テレビ・ラジオ & 0.146 & 0.001 & 0.073 \\
情報入手源 : インターネット & -0.088 & 0.090 & -0.053 \\
\hline 調整済み決定係数 & \multicolumn{4}{c}{0.078} \\
$\mathrm{~N}$ & \multicolumn{4}{c}{401} \\
\hline
\end{tabular}

$* * \mathrm{p}<0.01, \quad{ }^{*} \mathrm{p}<0.05$.

表 3 マスメディアの犯罪報道に対する意識についての重回帰分析

\begin{tabular}{|c|c|c|c|c|c|c|c|c|c|c|c|c|}
\hline & \multicolumn{4}{|c|}{ 事実を正確に伝えている } & \multicolumn{4}{|c|}{$\begin{array}{c}\text { 事件が興味本位で } \\
\text { 伝えられている }\end{array}$} & \multicolumn{4}{|c|}{$\begin{array}{c}\text { 事件の問題点や背景に } \\
\text { 迫って報じている }\end{array}$} \\
\hline & $\mathrm{B}$ & & S.E. & $\beta$ & $\mathrm{B}$ & & S.E. & $\beta$ & $\mathrm{B}$ & & S.E. & $\beta$ \\
\hline (定数) & 1.521 & $* *$ & 0.394 & & 2.804 & $* *$ & 0.404 & & 2.221 & $* *$ & 0.375 & \\
\hline 女性ダミー & 0.096 & & 0.073 & 0.062 & -0.020 & & 0.076 & -0.013 & 0.218 & $* *$ & 0.070 & 0.147 \\
\hline 年齢 & 0.003 & & 0.003 & 0.053 & -0.002 & & 0.003 & -0.032 & -0.010 & $* *$ & 0.003 & -0.196 \\
\hline 杉並区居住ダミー & -0.189 & $*$ & 0.078 & -0.122 & 0.141 & & 0.080 & 0.092 & -0.124 & & 0.074 & -0.084 \\
\hline 子どもありダミー & 0.174 & $*$ & 0.083 & 0.112 & -0.280 & $* *$ & 0.086 & -0.182 & 0.292 & $* *$ & 0.080 & 0.197 \\
\hline 本人教育年数 & 0.038 & & 0.022 & 0.090 & 0.005 & & 0.023 & 0.013 & 0.022 & & 0.021 & 0.055 \\
\hline 世帯年収 & 0.008 & & 0.021 & 0.018 & 0.045 & $*$ & 0.022 & 0.110 & 0.005 & & 0.020 & 0.012 \\
\hline 情報：新聞 & -0.083 & & 0.079 & -0.052 & 0.033 & & 0.081 & 0.021 & 0.010 & & 0.075 & 0.006 \\
\hline 情報 : テレビ・ラジオ & 0.463 & $* *$ & 0.095 & 0.234 & -0.058 & & 0.099 & -0.029 & 0.256 & $* *$ & 0.092 & 0.135 \\
\hline 情報 : インターネット & -0.326 & $* *$ & 0.087 & -0.195 & 0.118 & & 0.090 & 0.072 & -0.402 & $* *$ & 0.083 & -0.252 \\
\hline 調整済み決定係数 & \multirow{2}{*}{\multicolumn{4}{|c|}{$\begin{array}{c}0.139 \\
402\end{array}$}} & \multirow{2}{*}{\multicolumn{4}{|c|}{$\begin{array}{c}0.055 \\
406\end{array}$}} & \multirow{2}{*}{\multicolumn{4}{|c|}{$\begin{array}{c}0.128 \\
406\end{array}$}} \\
\hline $\mathrm{N}$ & & & & & & & & & & & & \\
\hline
\end{tabular}
$* * \mathrm{p}<0.01, \quad * \mathrm{p}<0.05$.

\section{5. 重回帰分析}

表 1 を踏まえて，2つの観点から検討を行いた い，ひとつは今述べた，居住地域による有意差が 出た項目についての変数を統制した検証である。 もうひとつはその前に論じた，マスメディアに対 する不信は，年齢によるものなのか，利用メディ
アによるものなのか，やはり変数を統制した検証 である。統制に用いる変数は，表 1 において独立 変数として用いた 4 項目に加え（学歴は「本人教 育年数」に置き換えて投入している)，子どもの有 無，世帯年収（8 段階）と，治安や犯罪に関寸る 情報源としての「新聞」「テレビ・ラジオ」「イン 
ターネット」の利用有無をそれぞれダミー変数と して投入している. ターゲット変数は順序を入れ 替え，「1．そう思わない，2，どちらかといえばそ う思わない，3．どちらかといえばそう思う， 4. そう思う」に変換して用いている.

まず居住地の効果の分析結果が表 2 である．表 2 で示した「未成年による非行・犯罪」の増減に ついては，クロス集計においてみられた居住地の 効果は消え, 年齢と本人教育年数のみが残る結果 となった。また，居住地の効果がクロス集計レベ ルでみられた「未成年による非行・犯罪は今より もっと厳しく処罰されるべきだ」については，重 回帰分析のモデル自体が成立しなかった。

次に，マスメディアの犯罪報道に対する不信に 関する項目の分析結果が表 3 である。新聞による 治安・犯罪情報入手の効果はみられなかったが， テレビ・ラジオを通して情報を得ていることで， 「事実を正確に伝えている」「事件の問題点や背 景に迫って報じている」といった報道の真正性に ついての評価が高まり, 逆にインターネットを通 して情報入手していることで評価が低くなる傾向 がみられた。特に前者について，二変数間レベル でみられた年代による顕著な違いは変数を統制す ることで，利用メディアの違いに吸収されたとい つてよいように思われる。インターネットにおけ る犯罪情報について同様の調查を行った場合に真 逆の結果が得られるのかどうかはやはり検証され る必要があるが，マスメディアの犯罪報道につい ては，それを視聴していることで真正性について の評価が高まり（あるいは自分がみている情報が
正しいという正当化が起こり），マスメディアとは 異なる視点からの情報を含むインターネットを利 用することで，その真正性の相対化ないしは否定 が起きているのではないかと考えられる。

表 3 に関して, 効果がみられた変数のうち, 子 どもの有無がどの変数にも効果をもつていること は当初想定していなかったものだった．モデルか らは除外しているが，既婚ダミーを投入しても効 果に変化はないため，子どもがいることで，マス メディアの犯罪報道に対して肯定的になる傾向が みられるといってよいように思われる．解釈とし ては，子どもがいることで被害リスクの認識が強 まり，同じ報道をより真剣にみるということがそ うさせているのかもしれないが，項目をより充実 させたさらなる検証が必要だろう。

\section{6. おわりに}

本稿での知見は，治安・犯罪に関する知見のさ さやかな積み増しではある。だが本稿は，メディ ア環境が大きく変わり，マスメディアの事件報道 を相対化しうるインターネットメディアが定着し た今日的状況において，メディア利用と犯罪につ いての意識に関連した，これまでにない知見を一 部提出することができたといえるように思われる. 今後の事件報道のあり方を考えていくにあたって， またマスメディアとインターネットの関係を考え ていくにあたって，そして私たちと犯罪報道の関 係性を考えていくにあたって，こうした調査を今 後より本格的なかたちで行うことは有益なことと いえるだろう。

（受付日：2020 年 3 月 22 日，受理日：2020 年 3 月 31 日）

\section{牧野 智和（まきの ともかず）}

現職 : 大妻女子大学人間関係学部准教授

早稲田大学大学院教育学研究科博士後期課程単位取得退学 博士 (教育学) 専門は社会学。自己の社会学，少年犯罪報道などに関する研究を行っている. 主な著書 : 日常に侵入する自己啓発（勁草書房） 